REITs: Structure and Performance

\author{
Walter I. Boudry \\ Assistant Professor of Real Estate, School of Hotel Administration, \\ Cornell University \\ Jarl G. Kallberg \\ Alvin C. Wolff Distinguished Professor of Real Estate, \\ Washington State University
}

Public Real Estate Markets and Investments (2014), 3(11), 195-212

The authors thank Sujith Puram, a finance doctoral candidate at Arizona State University, for assistance in preparing this manuscript. 


\section{REITs: Structure and Performance}

Introduction

REITs are attractive to investors, particularly institutional investors, due to their high dividend payouts and ability to provide more liquidity to the underlying market for direct real estate investment. This chapter analyzes the performance of real estate investment trusts (REITs). It compares the returns on REITs with those on more traditional asset classes, specifically bonds and mid-cap equities, and surveys the academic literature dealing with the diverse issues related to valuation. The chapter also examines the linkages between REIT performance and the behavior of the underlying real estate market. Because the chapter takes the perspective of a U.S.-based investor, it does not directly address the broader issues of global REITs.

\section{REIT Performance}

The original design of REITs was to provide individual investors with more liquid access to commercial real estate markets. Their structure as an essentially tax-free conduit with severe restrictions on possible investments and dividend payout made REITs a very transparent and liquid asset class that has undergone many structural changes. This section documents the explosive growth and inconsistent performance of REITs.

\section{MARKET SIZE}

REITs have undergone a remarkable spurt of growth since their introduction in 1965 with the listing of Continental Mortgage in the United States. Figure 11.1 shows the number of REITs and market capitalization (cap) in billions of U.S. dollars from 1971 until the end of 2012. In 
1971 there were 34 public REITs with a total market cap of $\$ 1.5$ billion. By the end of 2012 this figure grew to 172 REITs, which was down from its highest level of 226 reached in 1994, with a total market cap of $\$ 603.4$ billion. This figure also underscores the immense shocks that this sector was exposed to during the financial crisis. From the 2006 level of \$438.1 billion, REIT capitalization plummeted to $\$ 191.7$ billion by 2008 , which was followed by a remarkable recovery to its current level.

Insert Figure 11.1 Here

Figure 11.1 data (taken from http://www.REIT.com) include equity REITs (those that own property), mortgage REITs (those that make loans or own MBS), and hybrid REITs (those that do both). In the earlier periods, mortgage REITs were the majority of the total REIT population, but by 1976 equity REITs eclipsed mortgage REITs as measured by market cap. The hybrid REIT market was comparable in size to the mortgage REIT sector until 2001 when the latter market enjoyed substantial growth. Mortgage REITs from a 2000 level of $\$ 1.6$ billion have become a $\$ 59$ billion market (almost 10 percent of the total REIT capitalization) while the hybrid REIT has essentially disappeared. This chapter focuses only on equity REITs.

\section{REAL ESTATE RETURNS}

Endowment funds, pension funds, mutual funds, and other types of institutional investors view real estate as an important investment category. This investment is done through securitized or direct form. Securitized real estate is through holding REITs or real estate mutual funds. Direct investment is via ownership of real estate assets. Thus, a subject of considerable importance is the different performance of direct as opposed to securitized real estate investment. 
A great advantage of publicly traded REITs is their transparency. By trading on major exchanges, like any public equity, determining historical return characteristics is straightforward and offers comparability. The National Association of Real Estate Investment Trusts (NAREIT) maintains an extensive website at http://www.reit.com. NAREIT offers detailed information on REIT performance by type and geographic region. The NAREIT index, which is used in this chapter, provides an accurate benchmark for the performance of U.S. commercial real estate.

For direct investment in real estate, performance measurement is more complex, largely due to the infrequency of trades. This lack of transaction prices requires inferring market values through appraisals. For many years the most important index was the NCREIF Property Index, which is an appraisal-based measure of the unlevered return on investment grade properties. Appraisal-based measures have several flaws, notably their tendency to smooth returns, which understates the true volatility. Chinloy, Cho, and Megbolugbe (1997) discuss this and other possible appraisal biases. The research surrounding this topic is extensive, as in Gatzlaff and Geltner (1998) and Geltner and Goetzmann (2000). Fisher, Geltner, and Pollakowski (2007) develop a quarterly transaction-based index (TBI) of property-level investment performance for major property types included in NCREIF. Their methodology extends earlier work by Geltner (1991) on commercial real estate indexes. The following empirical work primarily focuses on the TBI index.

\section{COMPARATIVE RETURNS}

To help frame the remainder of the analysis, presenting an overview of the returns on REITs and other major investment classes is instructive. Figure 11.2 shows the growth of $\$ 1$ invested in five broad asset classes: (1) 10-year government bonds, (2) 90-day Treasury bills, (3) 
REITs as measured by the FTSE NAREIT index, available from http://www.reit.com, (4) capital appreciation on direct real estate investment as measured by the MIT TBI transaction-based index, available from http://web.mit.edu/ere/research/credl/tbi.html, and (5) returns on mid-cap stocks. The last is a value-weighted index constructed from U.S. equities in the third to seventh deciles of market cap, based on data from Wharton Research Data Services (WRDS). The data begin in the first quarter of 1984 to coincide with the initiation of the TBI index and end in the last quarter of 2012 .

Over this 29-year period, a dollar invested in government bonds grew to 10.6 (a geometric annual return of 8.48 percent); a dollar invested in Treasury bills grew to 3.24 (a geometric return of 4.14 percent); and a dollar invested in mid-cap equities returned 18.26 (a geometric return of 10.54 percent). The REIT index geometric return was 9.11 percent. This return is in sharp contrast to the very modest gains shown by the TBI index, which had a geometric return of only 2.35 percent. The real estate slump of the 1990 s depressed this index; it returned to its 1984 value only in 1997 and its current level of 196 is similar to values attained in 2006. These observations indicate that REIT returns come primarily from income rather than capital appreciation. Decomposing the total REIT return into these two components over the entire period for which data are available from 1978 to 2012 results in an average annual return from capital appreciation of 3.48 percent. The average annual return from income is 8.83 percent.

Insert Figure 11.2 Here

Figure 11.2 suggests that REIT returns are most closely correlated to the returns on midcap equities. The correlation with direct real estate and with bond returns is of lower magnitude. 
Figure 11.3, which computes the rolling five-year correlations between the REIT returns and other three indexes, makes these observations more precise. Over the entire sample period the correlation between REIT and mid-cap returns is 0.66 . However, using a GARCH approach, Jirasakuldech, Campbell, and Emekter (2009) show significant differences in the volatility structure of REITs versus small-cap equities. The REIT correlation with the TBI returns is only 0.058 and with bond returns it is -0.065 . NCREIF returns are only weakly correlated $(0.175)$ with REIT returns. The correlation with bond returns is positive until about 2000 and then is generally significantly negative. These results are consistent with earlier REIT empirical analysis. For example, Liu and Mei (1992) use a Generalized Method of Moments (GMM) approach to uncover the time varying risk premiums.

The lack of correlation of REIT returns with appreciation of the underlying properties is an important characteristic of REITs and will be explored further. These results are generally consistent with those obtained in Feldman (2003) during the 1987-2001 period. Similarly, using a vector autoregression approach, Glascock, Lu, and So (2000) show that REITs are more correlated with small stocks and less correlated with bonds after 1992.

\section{Insert Figure 11.3 Here}

Table 11.1 summarizes the key statistics for the return series studied in this chapter. Again the table shows that REIT returns more closely resemble the returns from mid-cap equities than the returns on the underlying real estate or bonds. REIT total returns lie between the returns on riskless bonds and the returns on mid-cap equities. These results are typical of those obtained in much earlier studies such as Goetzmann and Siegel (1984). With the exception of the REIT 
income returns, the series show moderate skewness, with the typical slightly negative skewness for the REIT and equity returns. Each series shows excess kurtosis or peakedness.

\section{SHARPE RATIOS}

An important way to measure the efficiency of investment in REITs versus more traditional instruments is via the Sharpe ratio, which is a standard measure of the (retrospective) risk-return trade-off as the excess return over the riskless rate divided by the returns standard deviation. However, the data from Table 11.1 show significant departures from the assumption of normally distributed returns, suggesting some caution in interpreting the Sharpe ratio in this context (Leland 1999). Figure 11.3 graphs the rolling six-year Sharpe ratio for the four return series. Specifically, the average realized quarterly returns net of the 90-day Treasury bill rate is computed for that quarter. This average excess return is divided by the standard deviation over the corresponding rolling six-year period. This estimation is rolled forward by one quarter until the data end.

\section{Insert Table 11.1 Here}

Over the entire sample bonds have the highest ratio ( 0.537$)$, followed by mid-cap equities $(0.456)$ and REITs $(0.354)$. The TBI has a negative ratio (-0.080). The Sharpe ratio for REITs is negative for the first few years of the 1990s but then remains positive for the remainder of the sample period. The REIT index has a lower standard deviation than the mid-cap equity series. Nevertheless, its average Sharpe ratio is still lower than that for mid-cap. These series show considerable nonstationarity, notably in the two real estate ones for REITs and TBI. Recent 
evidence suggests that REIT returns exhibit very significant and abrupt regime shifts (Peng and Schulz 2012; Bianchi and Guidolin 2013).

\section{FACTOR MODELS}

The final analysis of REIT returns is through estimation of a simple return-generating model. These models establish a linkage between the REIT index returns and return indexes of related investments. Such models usually relate REIT returns to a bond index since their high dividend payout makes REITs a reasonable substitute for bonds. The models also include an equity index because REITs are a type of mid-cap equity. The third factor relates to the returns on the underlying real estate market. The estimated model is the following:

$$
R_{t}=\alpha+\beta_{1} \text { Bond }_{t}+\beta_{2} \text { Midcap }_{t}+\beta_{3} T B I_{t}+\beta_{4} N C R E I F_{t}+\varepsilon_{t}
$$

where $R_{t}$ is the REIT index return in quarter $t$; $\alpha$ is a constant; Bond ${ }_{t}$ is the 10 -year government bond return in quarter $t$; Midcap $p_{t}$ is the return on the mid-cap index in quarter $t$; $T B I_{t}$ is the appreciation in the TBI index in quarter $t$; and $N C R E I F_{t}$ is the return on the NCREIF index in quarter $t$. Using both real estate return indexes can hopefully capture the income and the capital appreciation components of the returns on direct investment in real estate.

Insert Table 11.2 Here

Table 11.2 shows the estimates from this regression over the periods 1984 to 1993,1994 to 2003 , and 2004 to 2012 . The table shows that the only consistently significant factor is the mid-cap return, which is significant at the 0.01 level in each of the three regressions. The bond factor is significant in the first and last period only. What is interesting is the varying ability of the model to match REIT returns. The $R^{2}$ in the first period is 0.405 and then falls to 0.197 in the 
second period before taking on its highest value of 0.745 over the most recent period. Clayton and MacKinnon (2003) document the rise in REIT idiosyncratic risk in the middle period. They attribute the decline in systematic risk to increased information flows and the greater presence of institutional investors. However, the results in Table 11.2 for the most recent decade make this explanation less plausible. This factor model estimation has some noteworthy implications: (1) it is highly nonstationary (i.e., the weights on the factors and the overall fit are quite different in the three estimation periods); (2) the bond factor is much less important than the mid-cap equity factor; and (3) the two return series for the underlying real estate returns are insignificant.

A subsequent section discusses further some reasons for and implications of the apparent lack of a linkage between the returns on direct and securitized real estate. Some of the main hypotheses for why securitized returns in the form of REITs may differ from returns on the underlying real estate as measured by the TBI are the following. First, REITs are a levered investment, while the TBI is unlevered. Because the market value of REIT debt or the REIT s cost of debt is not observed, accurately de-levering the REIT returns or levering the TBI returns to make them perfectly comparable to the REIT index is difficult.

Second, because REITs are traded equity, their value should impound expectations of future economic conditions in an efficient market. The TBI may embed future economic conditions through the most recent transactions underlying the index. However, it is unlikely to be as forward looking as the publicly traded equity markets. Several studies analyzing the leadlag relationship between real and securitized real estate markets generally find that the securitized market leads the underlying market. Yavas and Yildirim (2011) provide recent example using a dynamic conditional correlation GARCH model. 
Third, the TBI may not actually measure underlying real estate returns very well. All underlying real estate returns are subject to estimation error or appraisal smoothing, depending on the index construction technique. Most properties do not sell during a given year. For those not selling, the valuation is estimated by an appraisal. That appraisal is smoothed when a previous valuation is adjusted by a preset percentage. Although such errors could be small, no guarantee exists that this is the case. The potential also exists that the assets in the TBI are not a perfect match for those owned by REITs. In hedging terminology, Boudry, Coulson, Kallberg, and Liu (2013) examine this basis risk for the TBI. They show that the tracking of the TBI to individual real estate properties is roughly comparable to the tracking of the S\&P 500 (SPX) to its individual components.

Fourth, REIT returns can be distorted due to noise trading (Black 1986). A noise trader makes investment decisions based on perceived market movements rather than a security s fundamentals. Thus, a noise trader buys when others are buying and sells when others are selling. Because REITs are traded equities, noise traders in the public equities markets potentially drive prices away from fundamental values. In such a situation, the correlation between REITs and the underlying real estate could be quite low, especially when the costs to exploit such mispricing are high. The references cited in the following section dealing with momentum in the return generating process develop these ideas further.

\section{RELATED LITERATURE ON REIT RETURN PROCESSES}

Although the previously discussed REIT return-generating results are similar to those presented in Clayton and MacKinnon (2003), they are not strictly comparable. The authors study REITs over a much earlier sample period: 1979 to 1998. Their return-generating process includes 
a large-cap and small-cap equity index, bond returns, and the NCREIF returns. Furthermore, they orthogonalize their factors and use a variance decomposition approach.

This subject remains an active area of research interest. Chui, Titman, and Wei (2003) and Derwall, Huij, Brounen, and Marquering (2009) provide considerable support for the presence of a momentum factor in REIT pricing. More recently, Goebel, Harrison, Mercer, and Whitby (2013) study momentum together with a "characteristic-based" approach in the spirit of Daniel and Titman (1998). This technique uses the underlying characteristics of a security such as the book-to-market ratio to explain differences in returns. Goebel et al. find that larger returns are associated with higher book-to-market ratios, less liquidity, and lower levels of institutional ownership. They further find that the premium associated with high book-to-market ratios is present only during periods of monetary expansion.

\section{REITS AS PART OF AN INVESTMENT PORTFOLIO}

Given the above discussion, one issue is how REITs fit within a typical pension or endowment fund portfolio. The early literature suggests that a 10 to 20 percent allocation to real estate is plausible (Fogler 1984; Firstenberg, Ross, and Zisler 1988). Kallberg, Liu, and Grieg (1996) use actual cash flow data from a portfolio of direct investment in real estate to re-examine this issue. Using integer programming to capture inherent "lumpiness" of real estate investment, they show that an allocation of about 9 percent is optimal. This latter figure seems to match the figures quoted by practitioners. For example, in a survey of more than 700 U.S. pension and endowment funds, Clayton (2007) finds that equity real estate represented 6.1 percent of total assets in 2006. Fugazza, Guidolin, and Nicodano (2009) show that adding REITs to the investment opportunity set can (out-of-sample) improve the investor s Sharpe ratio. 
Factors Driving REIT Performance

The remainder of this chapter addresses the determinants of differences in REIT performance. Although the following analysis is not exhaustive, it examines several possible factors.

- Corporate governance. Does the degree to which the REITs governance structure binds shareholders and managers influence value?

- Insider ownership. How does the increasing presence of institutional investors affect REIT returns?

- Dividends. Given the severe constraints on dividend payouts, can REIT dividend policy sway valuations?

- Underlying real asset market. How closely are REIT returns linked to the underlying asset market?

\section{REIT VALUATION AND CORPORATE GOVERNANCE}

The separation of ownership and control of the firm provides much of the impetus for corporate governance. Shleifer and Vishny (1997) provide a review of the corporate governance literature. Researchers have devised various control mechanisms including performance-based compensation contracts, board structures, anti-takeover provisions, ownership structure, and takeovers in an attempt to mitigate the potential shareholder- manager conflicts. A relevant issue is whether a REIT s governance structure influences its valuation. On the surface, corporate governance should not appear to have a major influence on REIT valuation. The restrictions on the payout of net income greatly reduce the possibility for diverting free cash flows as originally established by Jensen (1986). This restriction also necessitates REITs maintaining their access to capital markets. Additionally, REITs are more transparent than regular corporations because they 
are constrained to engage only in passive real estate activities and are essentially a collection of tangible assets. Buttimer, Hyland, and Sanders (2005), who find no evidence of long-term REIT post-initial public offering (IPO) outperformance, corroborate this observation.

Conversely, the lack of large blocks of shareholders suggests the need for corporate governance in REITs (Ling and Ryngaert 1997). McConnell and Servaes (1990) cite a substantial holding by insiders as a powerful governance mechanism. Friday, Sir- mans, and Conover (1999) document a non-linear relationship between insider ownership and market-tobook ratios. For equity REITs, levels of insider ownership below 5 percent lead to higher levels of market-to-book; higher levels have a negative impact. Analyzing Tobins $\mathrm{Q}^{\wedge}$ and insider ownership, Han (2006) finds a similar result when accounting for the UPREIT structure. Edelstein, Sureda-Gomila, and Urosevic (2010), who offer a more recent theoretical and empirical approach, show that the aggregate insider stake in a REIT declines over time.

Because many diverse governance mechanisms can be considered as substitutes, several studies use aggregated governance measures. Bianco, Ghosh, and Sirmans (2007) use the Gompers-Ishii-Metrick G-measure (Gompers, Ishii, and Metrick 2003), which uses 24 governance characteristics usually coded in binary form and then added to measure the strength of shareholder rights. They conclude that the impact of governance and valuation is unresolved. This result maybe partially due to the relative scarcity of hostile takeovers.

Using Tobins Qj Hartzell, Kallberg, and Liu (2008) show that corporate governance plays an important role in the IPO valuation of a REIT. Qis defined as the (offer price $\mathrm{x}$ shares outstanding + total assets - book equity) divided by total assets. It is measured at the IPO stage to mitigate possible endogeneity problems. After including various control variables to explain the IPO Q, the authors find that higher valuations are associated with lower management fees or 
compensation, more variable or incentive-based compensation, and greater insider ownership. More than half of publicly traded REITs are incorporated in Maryland, usually as trusts. Maryland offers greater liability protection, easier bylaw amendments and protection against hostile takeovers. A strong negative valuation effect also occurs for incorporation in Maryland, which is a state known to be management friendly. They find similar results regarding post-IPO performance and governance.

More recently, Bauer, Eichholtz, and Kok (2010) use the Corporate Governance Quotient index of Institutional Shareholder Services to examine the linkage between the level of corporate governance and REIT performance. They find that governance is significantly related to firm value only for REITs with low payout ratios. These low payout ratios can result from multiple sources, including managerial compensation, non-property expenses or high levels of capital expenditures.

\section{INSTITUTIONAL OWNERSHIP AND FIRM PERFORMANCE}

In many ways REITs act like regular corporations and in other ways they do not. Institutional ownership is one place where REITs as an industry are likely to behave differently from non-REITs. The reason for this is that ownership tests form part of the requirements to maintain REIT status. So unlike regular firms that do not face these restrictions, regulation imposes a friction on the ownership structure of REITs.

\section{REIT OWNERSHIP REQUIREMENTS}

Internal Revenue Code section 856 provides the ownership requirements that REITs face in order to maintain REIT status. REIT ownership essentially has two requirements. First, as 
stated in section 856(a)(5), the firm must have at least 100 beneficial owners. For most publicly traded companies, this is unlikely to be a major restriction. However, it is potentially an issue for private investors wanting to use the REIT structure. Second, the firm cannot be closely held, which is covered in section $856(\mathrm{~h})$. This second restriction is what is commonly referred to as the "five or fewer" rule, and essentially states that no five or fewer persons can own 50 percent or more of the REIT. Although the rule itself is somewhat more complicated than it is commonly phrased, the end result is that serious limits exist on concentrated ownership.

The Omnibus Reconciliation Act of 1993 included a look-through provision related to pension fund ownership in REITs. This provision allowed a fund to be considered as the set of its beneficiaries, rather than as a single entity. The impact of this provision was to make all the beneficiaries of the pension fund individual owners from the perspective of the five or fewer rule. As Downs (1998) shows, this made institutional investment in REITs by pension funds a much more attractive proposition and led to an increase in institutional ownership in REITs.

\section{REIT INSTITUTIONAL OWNERSHIP}

Figure 11.4 reports the level of institutional ownership for equity REITs (solid) and nonREIT (dotted) firms from 1990 to 2010 . Thomson Reuters 13(f) data serve as the basis for calculating the level of institutional ownership. Before 1994, fairly low levels of institutional ownership in REITs occurred. This is consistent with the finding of Chan, Leung, and Wang (1998) who show that before 1994 on a size-matched basis REITs had lower levels of institutional ownership than non-REITs. After 1994 and the enactment of the look-through provision, a sharp increase took place in the level of institutional ownership in REITs. By 1996 the average level of institutional ownership was higher in the REIT market than for non-REITs. 
Institutional ownership remained steady during the late 1990s and started to increase again around 2001. Although a similar upward trend in ownership occurred for non-REITs during the post 2001 period, it is more dramatic in the REIT sample. The likely explanation for this is that the first REITs entered the S\&P 500 in 2001. Ambrose, Lee, and Peek (2007) show that index inclusion caused a change in the price dynamics of REITs. Included REITs became more highly correlated with the index, but spillover effects arose for the rest of the REIT industry, making non-index REITs more highly correlated with the general stock market. Along these same lines, Chiang (2010) shows that higher levels of institutional ownership are related to higher levels of synchronicity with REITs of the same asset type.

Finally, the impact of the global financial crisis can be seen on the level of REIT institutional ownership in the latter part of the sample. Although ownership levels remained fairly stable for non-REITs, REIT institutional ownership fell dramatically at the start of the financial crisis but has since rebounded to near pre-crisis levels. Devos, Ong, Spieler, and Tsang (2013) show that during this period, institutional investors displayed a flight to quality by investing in REITs that were larger and had lower betas.

\section{Insert Figure 11.4 Here}

Table 11.3 reports ownership data by market cap decile for 138 firms in the FTSE/ NAREIT equity REIT index in the first quarter of 2013. The source of the FTSE/ NAREIT index constituent list is the NAREIT web page (http://www.reit.com) and SNL is the source for all other data. Three results are apparent from the table. First, only small REITs appear to have low levels of institutional ownership on average. Apart from the first decile of REITs, all other size deciles have institutional ownership greater than 70 percent. The REITs in the bottom decile are 
true micro-cap stocks. They have an average market cap in the bottom 5 percent of all Center for Research in Securities Prices (CRSP) listed stocks. Second, a nearly monotonic relationship exists between size and institutional ownership. Institutional owners almost exclusively hold large firms. Finally, an inverse relationship exists between inside and institutional ownership. Inside ownership tends to decline as firms become larger, while institutional ownership increases.

\section{THE IMPACT OF INSTITUTIONAL OWNERSHIP ON PRICING}

The prevailing assumption in corporate finance is that higher levels of institutional ownership have a positive influence on equity returns (McConnell and Servaes 1990). Institutional ownership could affect firm performance through several potential mechanisms. Gompers and Metrick (2001) describe one channel where institutional ownership is associated with higher returns. They contend that if the demand and supply curves for stocks are not perfectly elastic; then demand shocks could cause changes in stock prices and thus returns. This is often called the price pressure effect. In this sense; institutional ownership may predict stock returns. Furthermore, if institutional investors have preferences for certain firm characteristics, then a shock to institutional ownership will have a disproportionately large effect on firms with those characteristics. Gompers and Metrick show that this appears to be the case for a large sample of firms. Institutions tend to favor larger, more liquid stocks that generally have low past returns. Higher levels of institutional investment predict higher future returns. 
Conversely, institutional investors may exhibit herding or return chasing behavior by channeling capital flows to REITs with recent superior performance. Using quarterly Federal Reserve Flow of Funds data, Ling and Naranjo (2003) find no empirical support for return chasing behavior in the modern post-1992 REIT era. However, their results indicate that capital flows can influence REIT returns. Ling and Naranjo (2005) use a vector autoregression approach on monthly and weekly mutual fund flows. They show some evidence of return chasing behavior and that inflows can positively influence REIT returns.

According to Ling and Ryngaert (1997), institutional ownership may lead to a change in price dynamics around REIT IPOs. They find that in the 1970s and 1980s, REIT IPOs tend to be overpriced and subsequently exhibit underperformance compared to other REITs during the 100 days after an IPO. This relationship reverses itself in the IPOs of the early 1990s. In this market, characterized by higher institutional ownership, IPOs tend to be underpriced by 3.6 percent on average. They modestly outperform other REITs during the 100 days after an IPO.

Rather than being due to demand shocks, Yan and Zhang (2009) contend that returns and institutional ownership are positively correlated because of information. Institutions may be better informed than other investors and exploit their informational advantage. In particular, they argue that short-term active investors are more likely to trade on information. Their evidence indicates that the total level of institutional ownership does not predict returns, but rather the ownership levels of short-term investors.

Institutional owners can also affect firm performance through a corporate governance mechanism. If one believes that institutional investors are better monitors than retail investors, then ownership may affect performance through better oversight of management. Chung, Fung, and Hung (2012) show institutional ownership has a positive effect on REIT efficiency. 


\section{REIT VALUATION AND DIVIDENDS}

Because the majority of REIT returns come from the dividend cash flow, various studies investigate how REIT dividend policy influences REIT valuation. Kallberg, Liu, and Srinivasan (2003) show a tie between REIT values and their dividend payout. They find that, unlike for equity indexes, present value and dividend pricing models cannot be rejected for REITs, reinforcing the link between REIT values and dividend payouts. This result is in contrast to the rejection of these models for equity indexes (Campbell and Shiller 1988).

The market reaction to dividend cuts by REITs is similar to the results obtained for regular corporations: dividend cuts (increases) receive a negative (positive) announcement effect (Wang, Erickson, and Gau 1993). Although this finding suggests that REIT managers have some discretion of dividend payouts, the issue of REIT dividends and performance remains an open question. As Boudry (2011) discusses, REIT dividends can be decomposed into discretionary and non-discretionary components. Because of the dividend distribution requirements imposed on REITs in order to maintain status, REITs in practice typically distribute at least 100 percent of their taxable income and capital gains in dividends each year. REITs are required to distribute 90 percent of funds from operations after reserves.

REITs apparently use discretionary dividends that do not have an obvious tax motivation to smooth the overall level of dividends. So the meaning of a high dividend payout for a REIT is unclear. The firm could have high taxable income or could be paying large discretionary dividends. Because the discretionary and non-discretionary make up of dividends is only known during the subsequent period, examining the markets reactions to discretionary and nondiscretionary dividends is difficult. 


\section{REITS AND THE UNDERLYING REAL ESTATE MARKET}

A central debate in the REIT literature is the issue of how linked are REITs and the underlying asset markets. The issue is important from a practical standpoint because pension fund and other investment portfolios often view REITs as a more liquid mechanism for participating in the real estate market. Their alternative is direct real estate investment with all of its problems with illiquidity, high transactions costs, and lack of transparency. Many practitioners believe that REITs and direct real estate have different risk and return properties. Feldman (2003) confirms this intuition using a mean-variance analysis. MacKinnon and $\mathrm{Al}$ Zaman (2009) present an opposing viewpoint.

However, the results in Tables 11.1 and 11.2, as well as Figure 11.2 suggest that REIT returns more closely resemble those on mid-cap stocks as opposed to the underlying real properties. A problem with much of the extant literature is its focus on short-term structural relations between the two markets. Boudry et al. (2012) use a cointegration framework to link the TBI index with REIT returns. Although they find that securitized returns lead the underlying real market, the two markets share a long-run equilibrium. Both REITs and direct property returns adjust toward this equilibrium.

Hartzell, Kallberg, and Liu (2005) examine a final aspect of the linkage between REITs and the underlying market. They find that the demand for investment capital drives the volume of REIT IPOs rather than adverse selection. This fact again suggests a complex temporal interaction between the two markets. 
Summary and Conclusions

This chapter has analyzed the historical performance of U.S. equity REITs and some factors underlying the differences in this performance. Measured in diverse ways including means and standard deviations of quarterly returns, Sharpe ratios, and factor models contemporaneously, the data show that REIT returns are more similar to mid-cap equities than to bonds or to the returns on the underlying real estate. These data also show how dynamic these relationships are. The Sharpe ratios vary widely over the sample timeframe. The R2s and the factor loadings in the return-generating model are very different in the three sample periods studied.

The second part of this chapter studied the possible factors that influence the risk and return of REITs. In general, strong corporate governance and higher levels of institutional ownership positively influence REIT returns. REITs are an important class of investments for institutional investors. The data show that in the largest size decile, institutional ownership is 93.1 percent of the total.

A REIT is often considered an equity that is relatively easy to value because of the constraints on its investment activities and its transparency. Yet, the literature surveyed in this chapter suggests a complex relationship between REIT returns and their possible determinants. In particular, the link between REIT returns and dividend policy is hard to characterize. Despite the recent refinements in measures of the returns on direct real estate investment, many issues remain unresolved concerning the linkages between the real and securitized real estate markets. 


\section{Discussion Questions}

1. Discuss the reasons for the apparent lack of a contemporaneous link between the performance of REITs and the performance of the underlying real asset market.

2. Explain why REITs may not require as strong a corporate governance structure as typical corporations.

3. Discuss why institutional investors hold an increasing percentage of REIT shares.

4. Compare the historical performance of REITs with mid-cap equities and riskless bonds. 
Figure 11.1

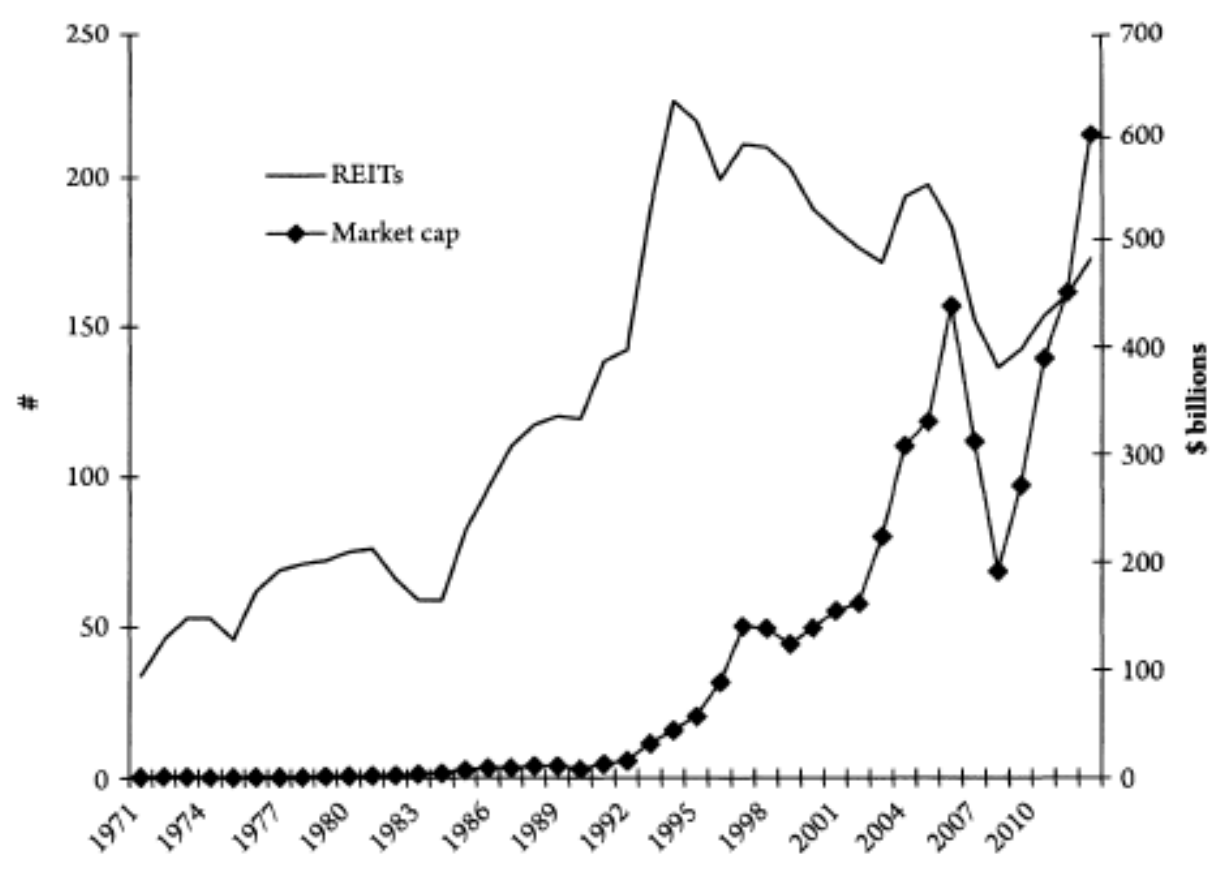

Figure 11.1 REIT Market Capitalization. This figure shows the number of REITs and the total market cap in billions of U.S. dollars from 1971 to 2012. The data include equity, mortgage, and hybrid REITs. 
Figure 11.2

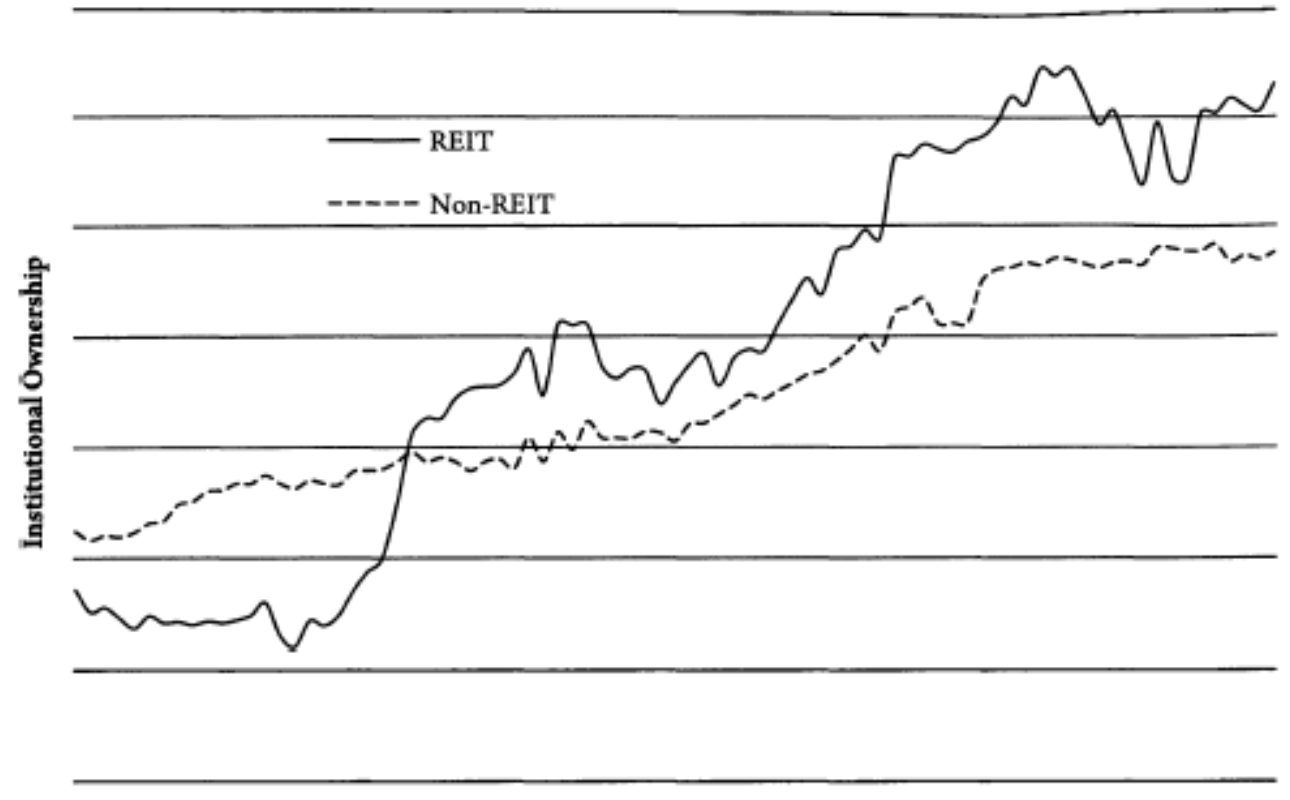

Figure 11.2 Institutional Ownership: REITs and Non-REITS. This figure reports the level of institutional ownership for equity REITs and non-REIT firms from 1990 to 2010. Thomson Reuters 13(f) data served as the basis for calculating institutional ownership. 
Figure 11.3

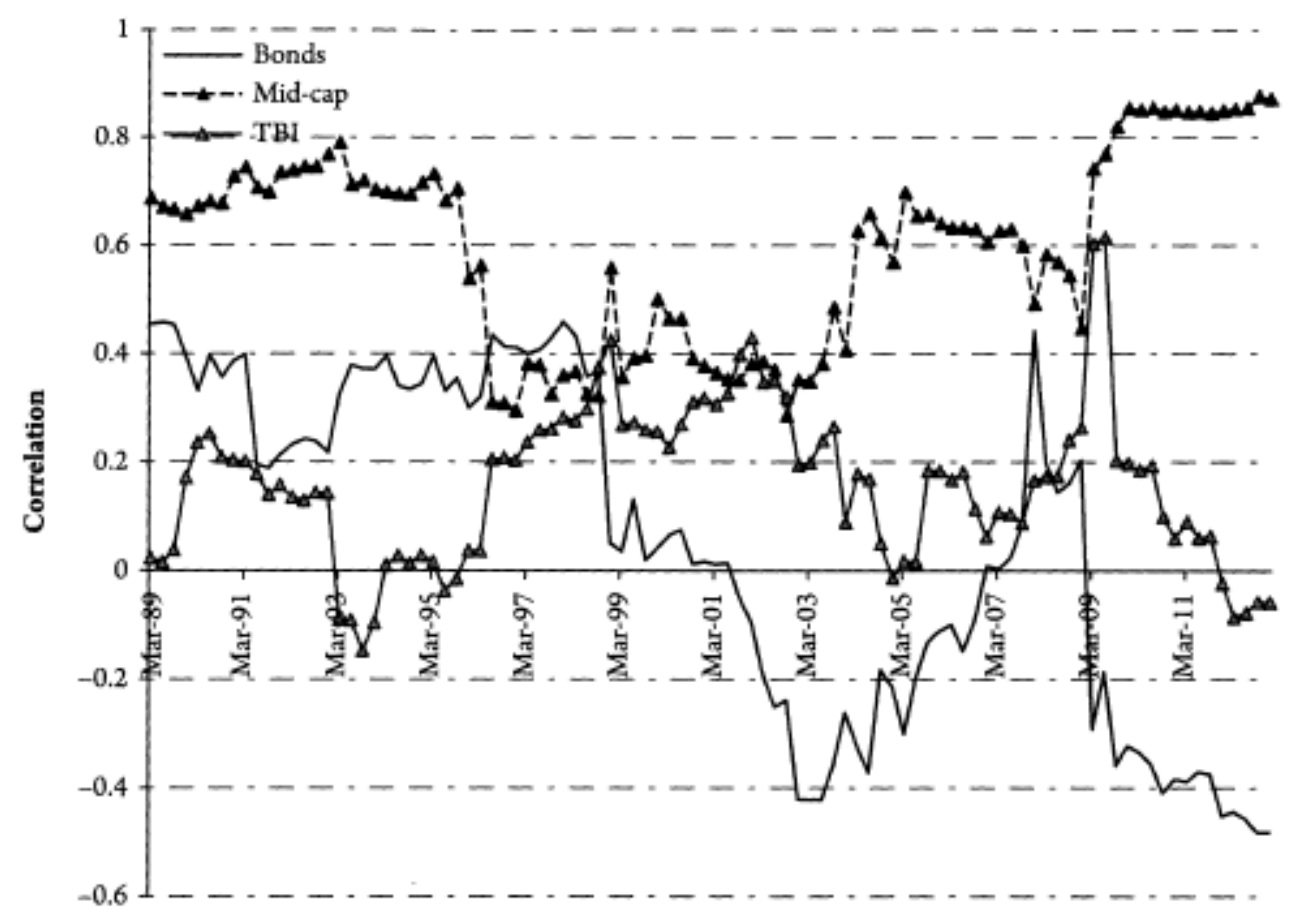

Figure 11.3 Rolling Correlations. This graph shows the rolling five-year correlations between the REIT index returns on the returns on 10-year government bonds, mid-cap equities, and the MIT/TBI index of real estate capital appreciation. 
Figure 11.4

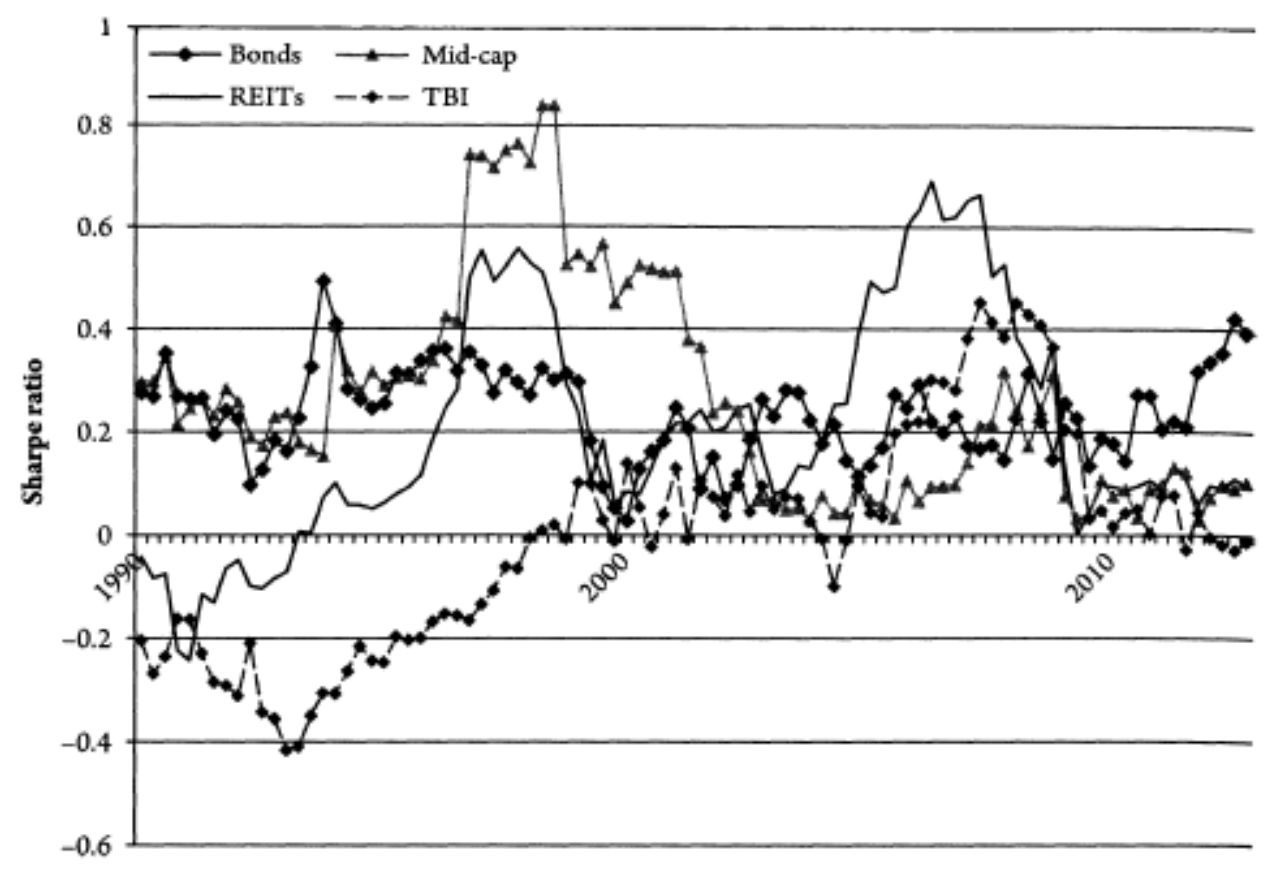

Figure 11.4 Sharpe Ratios. This figure shows the rolling six-year Sharpe ratios for the four return series emphasized in the analysis. 
Table 11.1

Table 11.1 Summary Statistics for Asset Returns from 1984 to 2012

\begin{tabular}{lrrrrr}
\hline Variable & Mean & Median & $\begin{array}{l}\text { Standard } \\
\text { Deviation }\end{array}$ & Skewness & Kurtosis \\
\hline 90-day Treasury bill & 5.16 & 5.01 & 3.54 & 0.62 & 3.32 \\
\hline 10-year government bond returns & 8.86 & 5.65 & 9.16 & 0.73 & 3.49 \\
\hline REIT capital returns & 3.48 & 4.51 & 17.81 & -0.69 & 6.40 \\
\hline REIT income returns & 8.83 & 8.30 & 1.55 & 3.28 & 22.59 \\
\hline MIT TBI index & 0.78 & 0.99 & 8.16 & -0.55 & 1.23 \\
\hline Mid-cap index total returns & 12.93 & 15.62 & 16.16 & -0.63 & 3.85 \\
\hline S\&P 500 & 9.45 & 12.67 & 16.21 & -0.54 & 3.61 \\
\hline
\end{tabular}

Note: This table presents the basic statistics for the return sample. The basic data are quarterly returns annualized beginning in the first quarter of 1978 and ending in the last quarter of 2012, except the TBI index, which begins in the first quarter of 1984. The data sources are NCREIF (http:// web.mit.edu/cre/research/credl/) and WRDS. The means, medians, and standard deviations are in percentages. 
Table 11.2

Table 11.2 Factor Model Regressions

\begin{tabular}{lccrrrr}
\hline $\begin{array}{l}\text { Estimation } \\
\text { Interval }\end{array}$ & Bond & Mid-cap & TBI & NCREIF & Adjusted $R^{2}$ & F statistic \\
\hline 1984 to & 6.128 & 0.496 & 0.036 & -0.291 & 0.405 & 7.64 \\
1993 & $(1.93)$ & $(4.33)$ & $(0.12)$ & $(-0.62)$ & & \\
\hline 1994 to & 0.936 & 3.84 & 0.139 & -1.787 & 0.197 & 3.39 \\
2003 & $(0.23)$ & $(3.10)$ & $(0.72)$ & $(-1.62)$ & & \\
\hline 2004 to & 15.548 & 1.487 & 0.145 & -0.058 & 0.745 & 22.61 \\
2012 & $(2.64)$ & $(8.19)$ & $(0.59)$ & $(-0.12)$ & & \\
\hline
\end{tabular}

Note: This table reports the estimation of the four-factor model:

$$
R_{t}=\alpha+\beta_{1} \text { Bond }_{t}+\beta_{2} \text { Midcap }_{t}+\beta_{3} \text { TBI }_{t}+\beta_{4} \text { NCREIF }_{t}+\varepsilon_{t}
$$

where $R_{t}$ is the REIT index return in quarter $t$; $\alpha$ is a constant; Bond $d_{t}$ is the 10-year government bond return in quarter $t$; Midcap $_{t}$ is the return on the mid-cap index in quarter $t$; $T B I_{t}$ is the appreciation in the TBI index in quarter $t$; and NCREIF $F_{t}$ is the return on the NCREIF index in quarter $t$. The estimation is done separately over the periods 1984 to 1993,1994 to 2003, and 2004 to 2012. The $t$-values are given in parentheses. 
Table 11.3

Table 11.3 REIT Ownership

\begin{tabular}{lcccc}
\hline Decile & $\begin{array}{l}\text { Number } \\
\text { of Firms }\end{array}$ & $\begin{array}{l}\text { Average Institutional } \\
\text { Ownership }\end{array}$ & $\begin{array}{l}\text { Average Inside } \\
\text { Ownership }\end{array}$ & $\begin{array}{l}\text { Average Market } \\
\text { Capitalization (in millions) }\end{array}$ \\
\hline 1 & 13 & 37.4 & 13.6 & 147 \\
\hline 2 & 14 & 72.5 & 7.5 & 488 \\
\hline 3 & 14 & 72.2 & 9.5 & 755 \\
\hline 4 & 14 & 73.4 & 10.0 & 1,121 \\
\hline 5 & 14 & 80.7 & 8.6 & 1,573 \\
\hline 6 & 14 & 88.9 & 4.0 & 1,996 \\
\hline 7 & 14 & 83.3 & 5.3 & 2,845 \\
\hline 8 & 14 & 90.9 & 3.2 & 3,925 \\
\hline 9 & 14 & 92.2 & 2.7 & 6,813 \\
\hline 10 & 13 & 93.1 & 4.6 & 21,166 \\
\hline Sample & 138 & 78.7 & 6.9 & 1,757 \\
\hline
\end{tabular}

Note: This table reports ownership data by market cap decile for 138 equity REITs in the FTSE/ NAREIT equity REIT index in the first quarter of 2013. Average institutional ownership is the average level of institutional ownership for firms in a given decile. Firms with ownership greater than 100 percent were winsorized to 100 percent. Average inside ownership is the average level of ownership of firm insiders for a given decile. Average market cap is the average market cap of firms in a given decile. The FTSE/NAREIT index constituent list is from NAREIT s web page (http://www.reit.com). SNL is the source for all other data. 


\section{References}

Ambrose, Brent W., Dong Wook Lee, and Joe Peek. 2007. "Industry Comovement after Joining an Index: Spillovers of Nonfundamental Effects." Real Estate Economics 35:1, 57-90.

Bauer, Rob, Piet Eichholtz, and Nils Kok. 2010. "Corporate Governance and Performance: Ihe REIT Effect.” Real Estate Economics 38:1, 1-29.

Bianchi, Daniele, and Massimo Guidolin. 2013. "Can Linear Predictability Models Time Bull and Bear Real Estate Markets? Out-of-Sample Evidence from REIT Portfolios. ” Journal of Real Estate Finance and Economics 43:2, 1-49.

Bianco, Candy, Chinmoy Ghosh, and C. F. Sirmans. 2007. "The Impact of Corporate Governance on the Performance of REITs.” Journal of Portfolio Management 33:1,175191.

Black, Fischer. 1986. "Noise.” Journal of Finance 41:3, 529-543.

Boudry, Walter. 2011. “An Examination of REIT Dividend Policy.” Real Estate Economics 39:4, 601-634.

Boudry, Walter, Edward Coulson, Jarl Kallberg, and Crocker Liu. 2012. "On the Hybrid Nature of REITs." Journal of Real Estate Finance and Economics 44:1,230-249.

Boudry, Walter, Edward Coulson, Jarl Kallberg, and Crocker Liu. 2013. "What Do Commercial Real Estate Price Indexes Really Measure?” Journal of Real Estate Finance and Economics 45:4, 617-639.

Buttimer, Richard, David Hyland, and Anthony Sanders. 2005. "REITs, IPO Waves, and Long Run Performance.” Real Estate Economics 33:1, 51-87.

Campbell, John, and Robert Shiller. 1988. "Stock Prices, Earnings and Expected Dividends." Journal of Finance 43:3,661-676.

Chan, Su Han, Wai-Kin Leung, and Ko Wang. 1998. "Institutional Investment in REITs: Evidence and Implications." Journal of Real Estate Research 16:3,357-374.

Chiang, Kevin C. H. 2010. "On the Comovement of REIT Prices." Journal of Real Estate Research 32: 2,187-200.

Chinloy, Peter, Man Cho, and Isaac F. Megbolugbe. 1997. "Appraisals, Transaction Incentives, and Smoothing." Journal of Real Estate Finance and Economics 14:1, 89-111.

Chui, Andy, Sheridan Titman, and K. C. John Wei. 2003. "Intra-Industry Momentum: The Case of REITs." Journal of Financial Markets 6:3, 363-387.

Chung, Richard, Scott Fung, and Szu-Yin Kathy Hung. 2012. "Institutional Investors and Firm Efficiency of Real Estate Investment Trusts." Journal of Real Estate Finance and Economics 45:1, 171-211. 
Clayton, James. 2007. PREA Plan Research Report. Hartford, CT: Pension Real Estate Association.

Clayton, James, and Gregory MacKinnon. 2003. "The Relative Importance of Stock, Bond and Real Estate Factors in Explaining REIT Returns." Journal of Real Estate Finance and Economics 27:1, 39-60.

Daniel, Kent, and Sheridan Titman. 1998. "Evidence on the Characteristics of Cross-Sectional Variation in Common Stock Returns." Journal of Finance 52:1; 1-33.

Derwall; Joroen; Joop Huij; Dirk Brounen; and Wessel Marquering. 2009. "REIT Momentum and the Performance of REIT Mutual Funds." Financial Analysts Journal 65:5; 24-34.

Devos, Erik; Seow-Eng Ong, Andrew C. Spieler, and Desmond Tsang. 2013. "REIT Institutional Ownership Dynamics and the Financial Crisis." Journal of Real Estate Finance and Economics 47:2, 266-288.

Downs, David H. 1998. "The Value in Targeting Institutional Investors: Evidence from the Fiveor- Fewer Rule Change." Real Estate Economics 26:4,613-649.

Edelstein, Robert, Antoni Sureda-Gomila, and Branko Urosevic. 2010. “Ownership Dynamics with Multiple Insiders: The Case of REITs.” Real Estate Economics 38:1, 57-90.

Feldman, Barry. 2003. Investment Policy for Securitized and Direct Real Estate. Chicago: Ibbotson Associates.

Firstenberg, Paul M., Stephen A. Ross, and Randall Zisler. 1988. "Real Estate: The Whole Story." Journal of Portfolio Management 23:1, 22-34.

Fisher, Jeff, David Geltner, and Henry Pollakowski. 2007. "A Quarterly Transactions-Based Index of Institutional Real Estate Investment Performance and Movements in Supply and Demand." Journal of Real Estate Finance and Economics 34:1, 5-33.

Fogler, H. Russell. 1984. "20 percent in Real Estate: Can Theory Justify It?” Journal of Portfolio Management 10:2, 6-13.

Friday, Swint, Stacy Sirmans, and Mitchell Conover. 1999. "Ownership Structure and the Value of the Firm: The Case of REITs.” Journal of Real Estate Research 17:1, 71-90.

Fugazza, Carolina, Massimo Guidolin, and Giovanna Nicodano. 2009. "Time and Risk Diversification in Real Estate Investments: Assessing the Ex Post Economic Value." Real Estate Economics 37:3, 341-381.

Gatzlaff, Dean, and David Geltner. 1998. "A Transaction-based Index of Commercial Property and Its Comparison to the NCREIF Index.” Real Estate Finance 15:1, 7-22.

Geltner, David. 1991. "Smoothing in Appraisal-Based Returns." Journal of Real Estate Finance and Economics 4:3, 327-345. 
Geltner, David, and Will Goetzmann. 2000. "Two Decades of Commercial Property Returns: A Repeated-Measures Regression-Based Version of the NCREIF Index." Journal of Real Estate Finance and Economics 21:1, 5-21.

Glascock, John, Chiuling Lu, and Raymond So. 2000. "Further Evidence on the Integration of REIT, Bond, and Stock Returns." Journal of Real Estate Finance and Economics 20:2,177-194.

Goebel, Paul, David Harrison, Jeffrey Mercer, and Ryan Whitby. 2013. "REIT Momentum and Characteristic-Related REIT Returns." Journal of Real Estate Finance and Economics 47:3, 564-581.

Goetzmann, Will, and Laurence Siegel. 1984. "Real Estate Returns: A Comparison with Other Investments." Real Estate Economics 12:3, 219-242.

Gompers, Paul A., Jay Ishii, and Andrew Metrick. 2003. “Corporate Governance and Equity Prices." Quarterly Journal of Economics 118:1,107-155.

Han, Bing. 2006. "Insider Ownership and Firm Value: Evidence from Real Estate Investment Trusts.” Journal of Real Estate Finance and Economics 32:4,471-493.

Hartzell, Jay, Jarl Kallberg, and Crocker Liu. 2005. "The Role of the Underlying Real Asset Market in REIT IPOs." Real Estate Economics 33:1, 27-50.

Hartzell, Jay, Jarl Kallberg, and Crocker Liu. 2008. "The Role of Corporate Governance in IPOs: Evidence from REITs." Journal of Law and Economics 51:3, 539-562.

Jensen, Michael C. 1986. "Agency Costs of Free Cash Flow, Corporate Finance, and Takeovers." American Economic Review 76:2, 323-329.

Jirasakuldech, Benjamas, Robert Campbell, and Riza Emekter. 2009. "Conditional Volatility of Equity Real Estate Investment Trust Returns: A Pre- and Post-1993 Comparison.” Journal of Real Estate Finance and Economics 38:2, 137-154.

Kallberg, Jarl, Crocker Liu, and Wylie Grieg. 1996. "The Role of Real Estate in the Portfolio Allocation Process." Real Estate Economics 24:3, 359-377.

Kallberg, Jarl, Crocker Liu, and Anand Srinivasan. 2003. "Dividend Pricing Models and REITs." Journal of Real Estate Economics 31:3,435-450.

Leland, Hayne. 1999. "Beyond Mean-Variance: Performance Measurement in a Nonsymmetric World." Financial Analysts Journal 55:1, 27-36.

Ling, David, and Andy Naranjo. 2003. "The Dynamics of REIT Capital Flows and Returns." Real Estate Economics 31:3,403-436.

Ling, David, and Andy Naranjo. 2005. "Dedicated REIT Mutual Fund Flows and REIT Performance." Journal of Real Estate Finance and Economics 32:4,409-433. 
Ling, David, and Michael Ryngaert. 1997. "Valuation Uncertainty, Institutional Involvement, and the Underpricing of IPOs: The Case of REITs." Journal of Financial Economics 43:3,433-456.

Liu, Crocker, and Jianping Mei. 1992. "The Predictability of Returns on Equity REITs and Their Co-Movement with Other Assets." Journal of Real Estate Finance and Economics 5:4,401-418.

MacKinnon, Greg, and Ashraf Al Zaman. 2009. "Real Estate for the Long Term: The Effect of Return Predictability on Long-Horizon Allocations.” Real Estate Economics 37:1,117153.

McConnell, John, and Henri Servaes. 1990. "Additional Evidence on Equity Ownership and Corporate Value.” Journal of Financial Economics 27:3, 595-612.

Peng, Liang, and Rainer Schulz. 2012. "Does the Diversification Potential of Securitized Real Estate Vary Over Time and Should Investors Care?" Journal of Real Estate Finance and Economics 41:4,409-433.

Shleifer, Andrei, and Robert Vishny. 1997. “A Survey of Corporate Governance.” Journal of Finance 52:2, 737-783.

Wang, Ko, John Erickson, and George Gau. 1993. "Dividend Policy and Dividend Announcement Effects for Real Estate Investment Trusts." Journal of the American Real Estate and Urban Economics Association 21:2, 185-201.

Yan, Xuemin, and Zhe Zhang. 2009. "Institutional Investors and Equity Returns: Are ShortTerm Institutions Better Informed?” Review of Financial Studies 22: 2, 893-924.

Yavas, Abdullah, and Yildiray Yildirim. 2011. "Price Discovery in Real Estate Markets: A Dynamic Analysis.” Journal of Real Estate Finance and Economics 42:1, 1-29. 